\title{
PENDIDIKAN ANTI KORUPSI DALAM PERSPEKTIF ISLAM
}

\author{
ADE KURNIAWAN
}

\begin{abstract}
Corruption always has a negative impact on the life of the nation and state. This dishonorable behavior has hurt the people's justice. Deviations on the basis of corruption have reduced the quality of the country to the community. Therefore it is necessary for the awareness of the whole community to participate in efforts to eradicate, eliminate, and minimize so that corruption can be prevented. The spirit of anti-corruption needs to be introduced to all levels of society, especially in the world of education, anti-corruption education is part of moral education in the perspective of Islamic religious education. Corruption is synonymous with, not trustful, dishonest and not grateful for all the blessings given by Allah Almighty and always feel lacking. Anti-corruption education is part of moral education in the perspective of Islamic religious education, where the source is from the Qur'an and hadis, which are expected to be able to manifest and develop virtue values in the younger generation, such as trustworthiness, responsibility, giving thanks to Allah's giving Almighty and honest as a form of piety and faith in Allah.
\end{abstract}

Keywords: Anti-corruption education, Islamic education, moral education

\section{Pendahuluan}

Korupsi selalu membawa dampak buruk bagi kehidupan berbangsa dan bernegara. Perilaku tidak terpuji ini telah melukai keadilan masyarakat. Penyimpangan atas dasar korupsi telah menurunkan kualitas negara kepada masyarakat. Korupsi juga telah mendistorsi pengambilan keputusan pada kebijakan publik. Di bidang lain yang lebih dekat dengan masyarakat, korupsi menyebabkan berbagai proyek pembangunan dan fasilitas umum bermutu rendah serta tidak sesuai dengan kebutuhan yang semestinya. Selain berdampak pada aspek kehidupan, korupsi juga menimbulkan efek yang meluas bahkan terhadap eksistensi bangsa dan negara. Korupsi dapat terjadi karena faktor internal dan faktor eksternal. Upaya pencegahan korupsi pada dasarnya dapat dilakukan dengan menghilangkan atau mengurangi kedua faktor penyebab korupsi tersebut.Apabila nilai-nilai anti korupsi tertanam dengan kuat di dalam diri setiap individu, faktor internal korupsi dapat dicegah. Nilai-nilai anti korupsi meliputi kejujuran, kemandirian, kedisiplinan, tanggung jawab, kerja keras dan keadilan.

Pengertian korupsi secara etimologi, berasal dari bahasa latin corruptusl corrupti. Dari bahasa Latin itu lah turun ke berbagai bahasa Eropa, seperti corruption dan corrupt di Inggris, corruption di Prancis, dan corruptie di Belanda. Dari bahasabahasa tersebut di sadur ke dalam bahasa indonesia yaitu menjadi korupsi. Korupsi merupakan kebalikan kondisi yang adil, benar, dan jujur. (Purwanto dan Fauzy, 2017:113). 
Menurut Undang-Undang No 31 Tahun 1999 juncto Undang-Undang Nomor 20 Tahun 2001 tentang Pemberantasan Tindak Pidana Korupsi, yang termasuk dalam tindak pidana korupsi adalah setiap orang yang dikatagorikan melawan hukum, melakukan perbuatan memperkaya diri sendiri, menguntungkan diri sendiri atau orang lain atau menyalahgunakan kewenangan maupun kesempatan atau sarana yang ada padanya karena jabatan atau kedudukan yang dapat merugikan keuangan negara atau perekonomian negara (Syahri., Mohd. Din., Mujibusalim, 2017:17).

Dengan berkembangnya ilmu pengetahuan definisi korupsi juga turut berkembang tidak hanya diperuntukan dalam skala besar yang dapat merugikan negara, tetapi juga sudah merembet dalam lembaga kecil, tindakan korupsi juga berpotensi untuk terjadi. Sedangkan definisi korupsi melalui pendekatan religius agam Islam, yaitu penjelasan dari Al Qur'an mengenai tindakan korupsi. Al Qur'an memandang tindakan korupsi atau penyalahgunaan wewenang.

a) Dijelaskan dalam Q.S. Al-Baqarah ayat 188 tentang larangan memakan harta yang bukan miliknya serta tentang suap-menyuap. "Dan orang-orang yang tidak mengetahui berkata: "Mengapa Allah tidak (langsung) berbicara dengan kami atau datang tanda-tanda kekuasaan-Nya kepada kami?" Demikian pula orang-orang yang sebelum mereka telah mengatakan seperti ucapan mereka itu; hati mereka serupa. Sesungguhnya Kami telah menjelaskan tanda-tanda kekuasaan Kami kepada kaum yang yakin (Q.S. Al Baqarah:188).

b) Dijelaskan dalam Q.S Ali-Imran ayat 161 mengenai larangan berhianat dalam urusan harta dan balasan di akhirat akibat dari mengambil harta orang lain dengan balasan yang setimpal. "Tidak mungkin seorang nabi berkhianat dalam urusan harta rampasan perang. Barangsiapa yang berkhianat dalam urusan rampasan perang itu, maka pada hari kiamat ia akan datang membawa apa yang dikhianatkannya itu, kemudian tiap-tiap diri akan diberi pembalasan tentang apa yang ia kerjakan dengan (pembalasan) setimpal, sedang mereka tidak dianiaya" (Q.S Ali-Imran:161).

c) Dijelaskan dalam Q.S An-Nisa' ayat 58 mengenai menyampaikan amanat dari orang lain sebagai bentuk kewajiban yang harus di sampaikan dan harus berprilaku adil bila memiki jabatan atau kedudukan. "Sesungguhnya Allah menyuruh kamu menyampaikan amanat kepada yang berhak menerimanya, dan (menyuruh kamu) apabila menetapkan hukum di antara manusia supaya kamu menetapkan dengan adil. Sesungguhnya Allah memberi pengajaran yang sebaikbaiknya kepadamu. Sesungguhnya Allah adalah Maha Mendengar lagi Maha Melihat" (Q.S. An-Nisa':58).

Dari beberapa penjelasan di atas di jelaskan bahwa tindakan korupsi atau bisa disebut penyalahgunaan wewenang bersumber dari Al-Qur'an, karena korupsi merupakan perbuatan yang di larang oleh allah swt, dan barang siapa yang melakukannya akan mendapatkan siksaan yang setimpal di akhirat. Serta bagi siapa yang memiliki jabatan hendak lah di pergunakan dengan semestinya sebagaimana yang telah Allah swt dan Rasul-Nya, menepati janji dan berperilaku adil (Budiman, 2017:9-10). 
Dari paparan di atas, dapat disimpulkan bahwa pengertian korupsi adalah perbuatan yang buruk, seperti penggelapan uang, penerimaan suap, dan sebagainya untuk memperkaya diri sendiri, orang lain, atau segala sesuatu yang dapat mengakibatkan kerugian keuangan negara, yang dilakukan oleh, orang-orang yang memiliki kepentingan dan kekuasaan, dalam hal ini korupsi merupakan perbuatan yang tidak terpuji yang dapat merugikan suatu bangsa dan negara.

Pentingnya pendidikan anti korupsi perlu diterapkan oleh setiap individu, mulai dari lingkunga keluarga, sekolah dan lingkungan masyarakat. Pendidikan anti korupsi merupakan bagian dari pendidikan Islam, karena pendidikan anti korupsi dapat kita gali dari al-Quran sebagai sumber hukum utama bagi umat Islam. Di dalamnya terdapat ayat yang menerangkan antara lain kewajiban taat kepada orang tua dan terhadap aturan pemerintan, yang semua itu merupakan bagian dari pendidikan anti korupsi. Dengan hidupnya ajaran dan nilai-nilai agama Islam tentang pendidikan anti korupsi secara aplikatif dalam kehidupan sehari-hari akan sangat berguna pada zaman modern sekarang ini. Ajaran dan nilai-nilai agama Islam akan menangkal pengaruh buruk modernisasi yang sedang melanda, serta akan menjadikan suasana kehidupan pribadi dan masyarakat yang tertata rapi dan hangat serta subur secara spiritual (Budiman, 2017:2-3).

Korupsi adalah penyakit masyarakat yang harus sesegera mungkin disembuhkan, Ibarat penyakit, Apabila tidak, penyakit ini akan semakin menyengsarakan masyarakat banyak. Masalah utama kasus korupsi beriringan dengan kemajuan, kemakmuran, dan teknologi. Semakin maju pembangunan suatu bangsa, semakin meningkat pula kebutuhan dan mendorong seseorang untuk melakukan korupsi. Diantara faktor-faktor penyebab seseorang melakukan tindakan korupsi menurut Purwanto dan Fauzy (2017:114), adalah: a) karena lemahnya iman; b) kurangnya akhlak dan moral; c) lemahnya penegakan hukum; d) faktor ekonomi; e) masyarakat yang membiarkan para pelaku melakukan praktik-praktik korupsi membuat para koruptor leluasa dan menjadi jalan mulus pagi para pelakunya. Penyebab timbulnya korupsi juga di sebabkan oleh sifat egoisme, yaitu adanya niat dan kesempatan. Artinya, jika ada niat untuk korupsi tetapi tidak ada kesempatan, maka korupsi tidak terjadi. Sebaliknya jika ada kesempatan untuk melakukannya tetapi niat melakukannya tidak ada, maka korupsi juga tak akan terjadi. Sehingga dapat disimpulkan bahwa korupsi adalah perpaduan antara moral dan sistem. Keegoisnme manusia membuat ia merubah sistem untuk kepentingan pribadi.

Jika dilihat dari kacamata agama (Islam) secara global, perbuatan korupsi ini bertentangan dengan tujuan Islam itu sendiri, yaitu untuk membahagiakan individu dan masyarakat serta mewujudkan kemaslahatan manusia. Akan tetapi ketiadaan hukum yang pasti dan tegas menyangkut kasus ini, baik dari segi positif maupun agama menyebabkan penyalahgunaan persepsi oleh sebagian masyarakat

Pendidikan anti korupsi bisa dipandang sebagai inovasi pendidikan, yang merespon kebutuhan masyarakat untuk menjadikan negara ini lebih transparan, maju, dan bebas korupsi. Wacana pendidikan anti korupsi didasarkan pada pemberantasan korupsi yang dilakukan secara integratif dan simultan yang berjalan beriringan dengan tindakan represif koruptor. Tujuan dari pendidikan anti-korupsi adalah membangun nilai-nilai anti korupsi dan mengembangkan karakter anak didik 
menjadi lebih baik dalam melawan korupsi. Pembelajaran anti korupsi bisa diterapkan baik secara formal maupun informal. Ditingkat formal, unsur-unsur pendidikan anti korupsi dimasukkan ke dalam mata pelajaran.

Pendidikan merupakan suatu proses membina seluruh potensi manusia sebagai: makhluk yang: beriman, berfikir, dan berkarya untuk diri dan lingkungannya. Islam juga sebagai agama yang sempurna telah memberikan pijakan yang jelas tentang tujuan dan hakikat pendidikan, yakni memberdayakan potensi fitrah manusia yang mengarah kepada nilai-nilai kebenaran dan kebajikan agar ia dapat menempatkan dirinya sebagai hamba.

Pendidikan Islam adalah usaha manusia untuk mendidik atau menjadikan orang lain beriman, bertakwa dan memiliki akhlak yang mulia. Dengan demikian pendidikan Islam merupakan sebuah proses transformasi fitrah manusia agar memperoleh keseimbangan hidup dalam semua aspeknya.

Pendidikan Islam bertujuan untuk menyempurnakan peserta didik menjadi manusia yang dapat hidup bahagia dunia maupun di akhirat dan untuk dapat menyempurnakan peserta didik dapat hidup bahagia dunia maupun di akhirat tidak hanya dengan memberikan pendidikan umum akan tetapi juga dengan memberikan dan menanamkan nilai-nilai Islam dalam peserta didik tersebut, sehingga dengan pendidikan agama tersebut dapat mengontrol segala tingkah lakunya di dunia serta dapat menyelamatkan hidupnya kelak di akhirat.

Pendidikan merupakan suatu proses membina seluruh potensi manusia sebagai: makhluk yang: beriman, berfikir, dan berkarya untuk diri dan lingkungannya. Islam juga sebagai agama yang sempurna telah memberikan pijakan yang jelas tentang tujuan dan hakikat pendidikan, yakni memberdayakan potensi fitrah manusia yang mengarah kepada nilai-nilai kebenaran dan kebajikan agar ia dapat menempatkan dirinya sebagai hamba.

Tujuan pendidikan Islam apabila melihat pengertiannya adalah untuk menjadikan peserta didiknya menjadi manusia beriman, bertakwa serta berakhlak mulia.

Tujuan umum pendidikan Islam ialah terwujudnya manusia sebagai hamba Allah. Jadi menurut Islam, pendidikan haruslah menjadikan seluruh manusia yang menghambakan kepada Allah. Yang dimaksud menghambakan diri ialah beribadah kepada Allah. Sedangkan menurut Rasyidi, (2015:5) tujuan pendidikan Islam adalah :

1. Tujuan yang berkaitan dengan individu, mencakup perubahan yang berupa pengetahuan, tingkah laku masyarakat, tingkah laku jasmani dan rohani dan kemampuan-kemampuan yang harus dimiliki untuk hidup di dunia dan di akhirat.

2. Tujuan yang berkaitan dengan masyarakat, mencakup tingkah laku masyarakat, tingkah laku individu dalam masyarakat, perubahan kehidupan masyarakat, memperkaya pengalaman masyarakat.

3. Tujuan profesional yang berkaitan dengan pendidikan dan pengajaran sebagai ilmu, sebagai seni, sebagai profesi, dan sebagai kegiatan masyarakat. 
Berdasarkan paparan di atas, maka penulis akan mengkaji bagaimana pendidikan anti korupsi dalam perspektif Islam.

\section{Metode}

Kajian ini menggunakan metode penelusuran literatur, khususnya literatur tentang korupsi dan pendidikan anti-korupsi. Melalui beberapa literatur, kajian ini berupaya mengungkap konsep Islam tentang pendidikan anti-korupsi.

\section{Konsep Pendidikan Anti Korupsi}

Pendidikan anti korupsi harus dikenalkan kepada anak sejak anak belajar tentang kehidupan, artinya sejak awal anak mulai dikenalkan nilai-nilai anti korupsi. Penanaman nilai yang dilakukan secara konsisten dan berkelanjutan, akan menumbuhkan sebuah sikap yang menjadi kepribadian anak. Pada dasarnya kepribadian seseorang tidak akan ada begitu saja, tapi harus melalui beberapa proses. Pendidikan anti korupsi ini dapat dilaksanakan secara formal maupun informal, secara formal yaitu dengan dimasukan kedalam kurikulum sekolah dalam setiap pelajaran. Sedangkan pada tingkatan informal dapat dilakukan dalam kegiatan ekstrakurikuler. Dengan memasukan nilai-nilai pendidikan anti korupsi seperti: kejujuran, kepedulian dan menghargai sesama, kerja keras, tanggungjawab, kesederhanaan, keadilan, disiplin, keberanian, dan kegigihan. kedalam proses pembelajaran, peserta didik diharapkan mampu berkembang menjadi pribadi yang lebih baik. Penanaman nilai ini jangan sebatas hanya dalam satu mata pelajaran, tapi perlu diberikan disemua mata pelajaran dan pada semua intansi pendidikan (Budiman, 2017:3).

Pendidikan anti korupsi harus diberikan melalui pembelajaran sikap mental dan nilai-nilai moral bebas korupsi di sekolah, sehingga para generasi muda bangasa Indonesia memiliki pandangan yang luas serta jauh dari segala tindakan korupsi. Oleh sebab itu perlu adanya penanaman nilai-nilai anti korupsi sejak dini, diharapkan melalui dunia pendidikan dapat menyelamatkan generasi muda suapaya tidak menjadi penerus tindak pidana korupsi. tetapi hanya saja memberikan pendidikan anti korupsi kepada peserta didik bukan lah perkara yang mudah. Sebab, terjadinya praktik korupsi berawal dari dunia pendidika yang cenderung tidak pernah memberikan paradigma berpriaku jujur dalam berkata dan berbuat termasuk sekolah-sekolah di negeri ini. Misalnya guru menerangkan hal-hal idealis dalam memberikan pelajaran, menabung pangkal kaya, tetapi realitanya banyak guru yang korupsi, seperti korupsi waktu, korupsi materi pelajaran yang diberikan,.korupsi berupa absen mengajar tanpa izin kelas. Hal-hal yang dilakukan itu, juga dapat memicu praktik korupsi yang lebih buruk di dunia pendidikan (Anam, 2015:16)

Tujuan Islam bertujuan membentuk pribadi Muslim seutuhnya, mengembangkan seluruh potensi manusia baik jasmani maupun ruhaniyah, menumbuhkan hubungan yang harmonis setiap pribadi manusia dengan Allah, manusia, dan alam semesta (Budiman, 2017:4). 
Dasar pendidikan Islam adalah Al-Qur'an dan Sunah Nabi saw. Di atas dua pilar inilah dibangun konsep dasar pendidikan Islam. Titik tolaknya dimulai dari konsep manusia menurut Islam. Manusia yang bagaimana yang dicita-citakan oleh Islam. Hal ini harus tergambar dalam tujuan, dari situ lahirlah materi apa yang akan diberikan untuk mencapai konsep tersebut.dari situ lahirlah materi apa yang akan diberikan untuk mencapai tujuan yang dikemas dalam kurikulum dan silabus. Setelah itu bagaimana menyampaikan materi tersebut, maka munculah metode pembelajaran. Supaya metode itu efektif dan efisien, diperlukan pula sarana dan fasilitas. Selanjutnya untuk mengukur apakah yang disampaikan itu telah dapat dipahami peserta didik atau sejauh mana daya serapnya terhadap materi yang diberikan, maka diperlukan evaluasi (Harto, 2014:128).

Dasar diartikan sebagai landasan untuk berdirinya sesuatu. Fungsi dasar ialah memberikan arah kepada tujuan yang akan dicapai. Karena setiap negara mempunyai dasar pendidikannya sendiri, dasar dapat di artikan sebagai sumber. Sumber pendidikan Islam yang dimaksud adalah semua acuan atau rujukan yang dari semua itu akan tertuang dalam pendidikan Islam. sumber pendidikan Islam itu sendiri terdiri dari enam macam, yaitu: Al-Qur'an, As-Sunna, kata-kata sahabat, kemaslahatan umat, tradisi atau adat kebiasaan masyarakat, dan hasil pemikiran para ahli dalam Islam. dari keenam sumber tersebut di awali dari sumber pertama yaitu Al-Qur'an, untuk kemudian dilanjutkan pada sumber-sumber berikutnya (Gaffar, 2016:204).

Pendidikan Islam bertujuan untuk menyempurnakan peserta didik menjadi manusia yang dapat hidup bahagia dunia maupun di akhirat dan untuk dapat menyempurnakan peserta didik dapat hidup bahagia dunia maupun di akhirat tidak hanya dengan memberikan pendidikan umum akan tetapi juga dengan memberikan dan menanamkan nilai-nilai Islam dalam peserta didik tersebut, sehingga dengan pendidikan agama tersebut dapat mengontrol segala tingkah lakunya di dunia serta dapat menyelamatkan hidupnya kelak di akhirat. Sebagaimana tujuan dari pendidikan Islam itu sendiri, yeitu : a) membantu pembentuk akhlak yang mulia; b) persiapan untuk kehidupan dunia dan akhirat; c) menumbuhkan roh ilmiyah; d) menyiapkan peserta didik dari segi profesional; e) persiapan untuk mencari rezeki (Gaffar, 2016:205).

Tugas utama pendidik selain mengajar, tugas-tugas lain mengajar adalah berbagai macam tugas yang sesungguhnya bersangkutan dengan mengajar, yaitu tugas membuat persiapan mengajar, tugas mengevaluasi hasil belajar, dan yang bersangkutan dengan tujuan pengajaran, menurut Al-Ghazal dalam (Sada, 2015:95) yaitu: a) wajib menemukan pembawaan yang ada pada anak didik dengan berbagai macam cara seperti, observasi, wawancara, melalui angket, pergaulan, dan lain sebagainya; b) berusaha menolong anak didik mengembangkan pembawaan yang baik dan menekan perkembangan pembawaan yang buruk agar tidak berkembang; c) memberikan kepada anak didik tugas orang dewasa dengan cara memperkenalkan berbagai bidang keahlian, keterampilan, agar nak didik memilih dengan tepat; d) engadakan evaluasi tiap waktu untuk mengatehui apakah perkembangan anak didik berjalan dengan baik; e) memberikan bimbingan dari penyuluhan tatkala anak didik mengalami kesulitan dalam mengembangkan potensinya. 
Ruang lingkup unsur-unsur pokok pendidikan Islam tersebut hanyalah merupakan garis-garis besarnya saja. Namun dapat dikembangkan dengan kebutuhan materi-materi apa yang akan diberikan kepada anak didik. Pada ranah keluarga pendidikan Islam difokuskan kepada dua hal yaitu : a) pendidikan moral; b) pendidikan sosial; c) pendidikan dasar-dasar keagamaan.

Pendidikan sosial dan dasar-dasar keagamaan merupakan hal awal dan utama. Segala tingkah laku, akan ditiru anak. Selain itu, peletakan pendidikan sosial merupakan hal yang penting. Kesadaran sosial pada anak dapat dipupuk sedini mungkin, lewat gorong royong serta, ketertiban, kedamaian, kebersihan dan keserasian dalam segala hal dan yang tak kalah pentingnya juga dalam memberikan pendidikan dasar-dasar keagamaan kepada anak. Misalnya tata cara shalat, berwudhu, bersuci, dan lain sebagainya.

Berdasarkan ruang lingkup pendidikan agama Islam yang telah dijelaskan tersebut dapat disimpulkan bahwa materi pendidikan agama Islam berada pada lingkup pendidikan akhlak dan ibadah serta ketauhidan kepada anak yang akan menjadi dasar pondasi yang kokoh bagi kehidupan keagamaan anak tersebut kelak dewasa.

\section{Pendidikan Anti korupsi dalam Pendidikan Agama Islam}

Berdasarkan prakteknya, korupsi merupakan satu hal yang sangat sulit untuk meberantasnya, karena sulit memberikan pembuktian-pembuktian yang eksak. Di samping itu, sangat sulit mendekteksinya dengan dasar-dasar hukum yang pasti. Namun akses perbuatan korupsi adalah suatu hal yang harus di waspadai oleh pemerintah maupun masyarakat. Salah satu langkah yang harus dilakukan oleh pemerintah dan masyarakat adalah perlunya pengetahuan akan nilai-nilai anti korupsi yang disampaikan melalui jalur pendidikan, sebab pendidikan merupakan satu instrumen perubahan yang mengedepankan cara damai, serta sangat potensial untuk pemberdayaan dan transformasi masyarakat berdasarkan model penguatan inisiatif manusiawi dan nuraniah untuk suatu agenda perubahan sosial.

Pendidikan adalah cermin masyarakat, Artinya kegagalan pendidikan berarti kegagalan dalam masyarakat. Demikian pula sebaliknya, keberhasilan pendidikan mencerminkan keberhasilan masyarakat. Pendidikan yang berkualitas akan menciptakan masyarakat yang berkualitas pula. Sebagai upaya pemberantasan korupsi, pemerintah terus berusaha untuk menangkap pelaku korupsi, namun upaya pemberantasan itu tidak akan cukup kalau hanya menagkap pelaku korupsi dan sosialisasi pemberantasan korupsi tidak akan cukup kalau hanya sekedar memberikan pemahaman tentang apa itu korupsi. Namun ada yang tidak kalah penting dalam upaya pemberantasan korupsi, yakni pencegahan korupsi. Pencegahan korupsi menjadi hal yang sangat penting dalam upaya pemberantasan korupsi. Oleh sebab itu, pencegahan korupsi harus diajarkan disetiap jenjang pendidikan. Pencegahan korupsi harus diajarkan disetiap jenjang pendidikan. dikarenakan: a) korupsi hanya bisa di hapus secara bertahap; b) pendidikan dalam upaya mencegah korupsi yaitu dengan menanamkan akhlak yang baik dan cinta tanah air; c) pendidikan untuk mengurangi korupsi harus berupa pendidikan nilai, yaitu pendidikan untuk mendorong setiap generasi menyusun kembali sistem nilai yang diwarisi (Budiman, 2017:2-3). 
Sangat mungkin bila korupsi bisa dihapus melalui sektor pendidikan, apabila semua elemen masyarakat dan pemerintah berusaha bersama-sama untuk memberantas korupsi dari berbagai aspek kehidupan. Upaya pencegahan korupsi bisa dilakukan dengan mencegai berkembangnya mental korupsi pada anak bangsa melalui pendidikan. Semangat anti korupsi yang patut menjadi kajian adalah penanaman pola pikir, sikap, dan perilaku anti korupsi melalui sekolah, karena sekolah adalah proses pembudayaan.

Pendidikan anti korupsi adalah perpaduan antara pendidikan nilai dan pendidikan karakter. Sebuah karakter yang dibangun di atas landasan kejujuran, integritas dan keluhuran. Pendidikan anti korupsi bagi anak-anak perlu ditanamkan sejak usia dini sebab mereka juga mempunyai potensi berlaku negatif. Dunia pendidikan memiliki tugas yang mulia untuk mencetak generasi-generasi bangsa yang anti korupsi dan berkarakter baik.

Menurut Harto (2014:127), dunia pendidikan memiliki tugas mulia untuk mencetak generasi-generasi bangsa yang anti korupsi. Penanaman nilai-nilai anti korupsi sangat mungkin dan efektif apabila dilakukan dilembaga pendidikan baik formal, non formal maupun informal. Penanman nilai-nilai anti korupsi yang berupa nilai kejujuran, kepedulian, kemandirian, kedisiplinan, tanggung jawab, kerja keras, kesederhanaan, keberanian, serta keadilan dapat menumbuh kembangkan semangat pantang menyerah untuk mencapai kebaikan dan kesuksesan. Berdasarkan konsep pendidikan anti korupsi tersebut, maka implikasinya dalam pendidikan agama Islam adalah sebagai berikut:

a. Kurikulum

Kurikulum adalah inti pendidikan, kurikulum merupakan bidang yang paling penting dalam memberikan pengaruh langsung terhadap perkembangan peserta didik. Pendidikan Islam, mencoba menampilkan model pendidikan anti korupsi dalam Pendidikan Agama Islam (PAI). Pendidikan anti korupsi yang dimaksud disini adalah program pendidikan anti korupsi yang secara konsepsional disisipkan pada mata pelajaran yang sudah ada disekolah dalam bentuk perluasan tema yang sudah ada dalam kurikulum dengan menggunakan pendekatan kontekstual pada pembelajaran anti korupsi, yaitu dengan model pendidikan anti korupsi integratif dalam materi pendidikan agama Islam.

Secara kurikulum pendidikan anti korupsi memang tidak masuk ke dalam satuan mata pelajaran yang ada disekolah, karena pendidikan anti korupsi dapat diberikan sebagai kegiatan ekstrakurikuler atau dengan menanamkan (menyisipkan) nilai-nilai pembelajaran anti korupsi secara terintegrasi dalam mata pelajaran yang sudah ada. Walaupun demikian tetap diperlukan adanya perumusan Standar Kompetensi dan Kompetensi Dasar untuk memasukkan muatan anti korupsi ke dalam mata pelajaran yang ada kaitannya dengan moral dan budi pekerti, seperti Kewarganegaraan dan Pendidikan Agama.

b. Guru

Guru adalah garda depan dari proses pendidikan, maka selayaknyalah guru menjadi teladan (diguguh dan ditiru). Selain sebagai teladan, guru juga mempunyai tugas penting sebagai motivator. Karena dalam Islam itu sendiri kedudukan ilmu itu 
sangat luar biasa. Bahkan kewajiban mencari ilmu itu sangat lah di anjurkan dalam Islam.

Pada hakikatnya pendidik dalam Islam adalah orang-orang yang bertanggung jawab terhadap perkembangan peserta didik dengan mengupayakan seluruh potensi anak didik baik potensi efektif, kognitif, maupun psikomotorik. Pendidik bererti juga orang dewasa yang bertanggung jawab memberi pertolongan kepada anak didik dalam perkembangan jasmani dan rohaninya, agar mencapai tingkat kedewasaan, maupun berdiri sendiri memenuhi tingkat kedewasaannya, maupun berdiri sendiri memenuhi tugasnya sebagai hamba dan khalifah Allah swt dan sebagai makhluk sosial, dan sebagai makhluk individu yang mandiri. Jika dilihat dari hakikat pendidik, maka jelas bahwa kehadiran seorang pendidik itu sangat diharapkan untuk perkembangan peserta didik agar mencapai tingkat kedewasaan yang diharapkan menjadi hamba yang selalu bertaqwa kepada Allah swt, dan memiliki akhlak yang baik.

\section{c. Pembelajaran}

Dalam pembelajaran, menurut Frimayanti (2015:97) diperlukan prinsip modeling. Artinya, siswa atau anak dengan mudah akan melakukan suatu perilaku tertentu melalui proses peniruan pada sang model. Siapapun, apakah itu orang tua, guru, maupun orang-orang yang dikaguminya. Sikap-sikap yang seharusnya ditanamkan adalah nilai-nilai anti korupsi seperti jujur, sikap jujur yang harus didasari dengan pendidikan keimanan, karena dalam pendidikan Islam itu sendiri masih saja ada ketidak jujuran, baik dikalangan pendidik maupun tenaga kependidikan. Jumlah lembaga pendidikan Islam semakin banyak, hampir di setiap desa, bahkan sampai kedaerah terpencil sekalipun. Tetapi masih ada saja praktik ketidak jujuran, yang seharusnya bila mana lembaga pendidikan Islam semakin banyak maka ketidak jujuran semakin menurun. Selain itu, sikap tidak jujur sering ditunjukkan oleh peserta didik, ketika sedang melaksanakan ujian, masih ada saja yang menyontek hasil jawaban temannya sendiri, atau menyembunyikan buku di bawah meja sebagai bahan contekan bila sedang ulangan. Untuk membenahi penyimpangan-penyimpangan tersebut, diperlukan pendidikan keimanan sebagai pangkal pembentukan sikap jujur. Dengan pendidikan keimanan maka setiap unsur dalam pendidikan, baik pendidik, tenaga kependidikan, maupun peserta didik, akan selalu merasa diawaso oleh Allah swt. Sehingga tidak akan melakukan kecurangan lagi. Dengan menanamkan sikap jujur dan tanggung jawab seperti mengajak peserta didik sedekah, infak, shalat lima waktu, puasa sunah, selalu bersyukur atas nikmat yang Allah swt berikan. Untuk inilah, salah satu unsur penting dalam pendidikan karakter adalah mengajarkan nilai-nilai itu sehingga peserta didik mempunyai gagasan konseptual tentang nilai-nilai pemandu perilaku yang dapat dikembangkan dalam mengembangkan karakter pribadinya. Pemahaman konseptual ini mesti menjadi bagian dari pemahaman pendidikan karakter itu sendiri, sebab peserta didik akan banyak belajar dari pemahaman dan pengertian tentang nilai-nilai yang dipahami oleh para guru.

Dengan di masukannya pendidikan anti korupsi dalam pelajaran pendidikan agama islam, yang mana di dalamnya memuat nilai-nilai yang berkaitan dengan pendidikan karakter. Pendidikan agama Islam juga adalah pelajaran yang paling 
dekat dengan nilai-nilai keislaman, dengan mengembangkan nilai-nilai keislaman yang sunber dasarnya dari Al-Qur'an dan hadis.

Melalui pendidikan anti korupsi sebagai bagian dari pendidikan akhlak dalam perspektif pendidikan agama Islam yang bersumber dari Al-Qur'an, dapat menanamkan dan mengembangkan beberapa nilai berikut yang menjadi dasar untuk mencegah perilaku korupsi.

1) Nilai-nilai amanah merupakan tanggungjawab yang dipikulkan kepada seseorang yang mana dia wajib menjaga dan melaksanakan amanah tersebut. Allah swt telah memerintahkan kepada orang-orang untuk melaksanakan amanah dengan sebaik-baiknya. Amanah yang terbesar yang diberikan kepada Allah swt yang di berikan kepada manusia yaitu amanah menjalankan syariat Islam dalam semua lini kehidupan manusia, dan amanah menjaga jasmani. Korupsi dilakukan oleh orang yang mengemban amanah atau orang yang memiliki wewenang tertentu. Setiap amanah akan diminta pertanggung jawabannya kelak di akhirat. Dalam AlQur'an terdapat beberapa ayat yang memperingatkan orang-orang yang mengemban amanah ini, diantaranya adalah: "Sesungguhnya Allah menyuruh kamu menyampaikan amanat kepada yang berhak menerimanya, dan (menyuruh kamu) apabila menetapkan hukum di antara manusia supaya kamu menetapkan dengan adil. Sesungguhnya Allah memberi pengajaran yang sebaikbaiknya kepadamu. Sesungguhnya Allah adalah Maha Mendengar lagi Maha Melihat" (Q.S. An-Nisa:58).

2) Bersyukur, cikal bakal terjadinya korupsi salah satunya ialah tidak bersyukurnya manusia atas nikmat yang diberikan oleh Allah SWT, sehingga terus saja merasa kekurangan. Harta yang halal dan baik akan mengantarkan seseorang pada tingkatan manusia yang banyak bersyukur. Hal ini dijelaskan melalui firman Allah, yaitu: "Hai orang-orang yang beriman, makanlah di antara rezeki yang baik-baik yang Kami berikan kepadamu dan bersyukurlah kepada Allah, jika benar-benar kepada-Nya kamu menyembah" (Q.S. Al-Baqarah:172).

Bentuk bersyukur kepada Allah merupakan bentuk keseriusan kita dalam beribadah kepada-Nya, entah ibadah pokok seperti shalat, zakat, puasa, haji, atau ibadah lainnya, seperti membaca Al-Qur'an, zikir, beramal sosial dengan membantu orang-orang yang kurang mampu sesuai dengan kemampuan. Karena salah satu yang dapat menjadikan seseorang malalukan korupsi dikarenakan kurang bersyukur atas nikmat yang telah Allah berikan, tidak pernah merasa cukup dengan apa yang dimiliki, minder atau rendah diri, dan sebagainya.

3) Nilai kejujuran. Nilai kejujuran juga merupakan akhlak yang penting dimiliki seseorang untuk membentengi diri dari virus korupsi. Jujur merupakan perbuatan yang dilakukan dengan tidak membohongi diri sendiri maupun orang lain. Nilai kejujuran dalam kehidupan sehari-hari merupakan fondasi awal dalam mencegah perbuatan korupsi. Seperti yang telah diajarkan di bangku sekolah tentang sifat terpuji dan tercela, bohong adalah salah satu perbuatan tercela. Kejujuran mengacu pada aspek karakter, moral, berkonotasi atribut positif dan berbudi luhur. Selain itu kejujuran berarti dapat dipercaya, setia, adil, dan tulus, karena kejujuran dihargai oleh banyak budaya etnis dan agama. Karena dalam agama Islam orang yang melakukan kebohongan adalah perbuatan dosa. Karena 
sekali berbuat bohong niscaya akan melakukannya yang kedua, ketiga dan seterusnya karena menutupi perbuatan yang pertama kali dilakukan.

Tanapa adanya tiga hal tersebut, bisa membuat orang lupa akan semua janji yang sudah seseorang katakan, kursi kekuasaan sering kali membuat orang lupa akan janji-janjinya pada waktu pelantikan jabatann yang mana semua itu di saksikan oleh banyak orang serta disaksikan oleh Allah swt. Harta yang melimpah seringkali membuat membutakan mata, menulikan telinga, merusak akal sehat, sehingga kepercayaan masyarakat yang di bangun sejak lama dikorbankan demi memuaskan keinginan kejinya.

Tindakan korupsi sangat bertentangan dengan prinsip amanah dan kejujuran yang diajarkan dalam agama Islam. Jika kedua nilai tersebut hilang maka kehancuran lah yang akan didapatkan. Kerena bila mana seseorang melakukan korupsi sudah jelas amanah dan kejujuran sudah hilang dalam dirinya begitupun keimanannya juga hilang. Pada akhirnya, kejahatan dan hukum bisa diperjualbelikan oleh oknum yang tidak bisa amanah. Sehingga tatanan kehidupan dan negara akan rusak. Dengan menanamkan nilai-nilai pendidikan anti korupsi diharapkan dapat mencegah itu semua terjadi lagi dimasa yang akan datang, dengan berpedoman pada Al-Qur'an dan hadis, proses pemberantasan korupsi akan lebih terarah, karena Al-Qur'an merupakan pedoman yang kebenarannya sudah tidah di ragukan lagi oleh semua umat Islam.

\section{Pendidikan Anti Korupsi Sebagai Pendidikan Akhlak}

Salah satu hakikat manusia di ciptakan sebagai makluk yang telah di berikan akal yang sempurna, sebagaimana di jelaskan dalam Q.S At-Tin ayat 4 yaitu: "Sungguh Kami telah menciptakan manusia dalam bentuk yang sangat baik (sempurna)" (Q.S At-Tin: 4).

Menurut Budiman (2017:6-7) kesempurnaan manusia ditandai kesempurnaan akal mebagai makhluk yang berpikir tidak terdapat pada makhluk-makhluk lainnya menjadi landasan logika yang paling mendasar. Akan tetapi, meskipun potensi terkuat yang dimiliki manusia adalah akal, kahidupan manusia tidak selalu berjalan mulus. Karena itu akal seharusnya digunakan untuk mengetahui mana yang hak mana yang wajib. Dengan akal manusia bisa mengubah peradaban. Interaksi dan perubahan peradaban, segala godaan akan kesenangan dan gemerlap kehidupan di dunia membuat hamba-hamba Allah yang kurang ilmu ini lupa akan konsekuensi yang diterima di akhirat kelak. Dalam ajaran Islam, yang terpenting adalah akhlak yang seimbang, yitu seimbang antara kehidupan duniawi dan ukhrawi dan seimbang dalam menerima hak dan melaksanakan kewajiban. Keseimbangan disebut dengan adil. Pembentukan akhlak ditunjang sepenuhnya oleh penerimaan akal dan hati terhadap ajaran-ajaran agama. Karena dalam kehidupan sosial, terdapat orang-orang yang saleh, dermawan, sadar, pemarah, dengki, pemaaf, dan sifat-sifat lain yang merupakan cerminan akhlak baik dan akhlak buruk, sebagaimana diterangkan dalam Q.S Asy-Syams ayat 8-10, yaitu: "Maka Allah mengilhamkan kepada jiwa itu (jalan) kefasikan dan ketakwaannya, sesungguhnya beruntunglah orang yang mensucikan jiwa itu, dan sesungguhnya merugilah orang yang mengotorinya"( Q.S Asy-Syams: 810). 
Berdasarkan firman Allah swt, bahwa hakikatnya, di setiap diri manusia semuanya memiliki nilai, yang mana nilai tersebut yang menentuka apakah itu termasuk kedalam akhlak baik atau akhlak buruk dengan semua tingkah laku yang dilakukannya. Setiap manusia memiliki kecendrungan melakukan perbuatan baik atau buruk. Ada salah satu manusia berbuat buruk dengan melakukan tindakan korupsi.

Pendidikan akhlak merupakan pendidikan yang berwawasan nilai-nilai keislaman, yang memiliki tujuan, untuk menciptakan manusia sebagai makhluk yang tinggi dan sempurna, serta membedakannya dari makhluk-makhluk lainnya, dengan akhlak akan membentuk peserta didik yang beriman dan bertakwa kepada Allah swt.

Perilaku korupsi yang dilakukan seseorang bersumber dari akhlak buruk yang dimilikinya. Dengan adanya pendidikan anti korupsi, dapat mencegah dari tindakan akhlak yang buruk. Dengan hadirnya pendidikan anti korupsi di Indonesia merupakan bagia dari pendidikan akhlak di sekolah, baik pendidikan formal atau non formal.

\section{Kesimpulan}

Korupsi merupakan masalah yang bersifat komplek, sehingga memerlukan pemecahan secara menyeluruh dalam berbagai bidang, serta bagaimana pemecahannya agar tindak pidana korupsi tidak terulang kembali di masa yang akan datang. Pendidikan anti korupsi menjadi salah satu altertatif dalam memecahkan masalah korupsi, dengan menanamkan kesadaran nilai-nilai Islam dalam pendidikan anti korupsi. Pendidikan akhlak menjadi salah satu cara untuk mewujudkannya. Pendidikan akhlak yang bersumber dari Al-Qur'an dan hadis. Dengan menanamkan pendidikan anti korupsi sejak dini, berarti sama hal-nya dengan menanamkan pendidikan akhlak yang baik, terutama yang berkaitan dengan pendidikan agama Islam untuk mewujudkan generasi anti korupsi. Dengan adanya pendidikan anti korupsi ini, diharapkan akan lahir generasi muda bangsa Indonesia tanpa korupsi sehingga di masa yang akan datang Indonesia terhindar dari korupsi.

\section{DAFTAR PUSTAKA}

Anam, Saiful, Arif, M. (2015). Lembaga Pendidikan Islam Sebagai Wahana Implementasi Pendidikan Anti Korupsi. Jurnal Pendidikan Agama Islam, 3 (2), 16-25.

Budiman, Amat. (2017). Pendidikan Anti Korupsi Sebagai Pendidikan Akhlak Dalam Pendidikan Agama Islam. Jurnal Pigur, 1 (1), 2-10.

Chaerudin et al. (2008). Strategi Pencegahan \& Penegakan Hukum Tindak Pidana Korupsi. Bandung: Refika Aditama. 
Frimayanti, Imelda, Ade. ( 2017). Pendidikan Anti korupsi dalam pendidikan Agama Islam. Jurnal Al-Tadzkiyyah: jurnal Pendidikan Islam, 8 (1), 97. http://ejournal.radenintan.ac.id

Gaffar, Abdul. (2016). Pendidikan Islam Berbasiskan Anti Korupsi. JurnalnPendidikan, 3 (2), 202-205.

Harto, Kasinyo. (2014). Pendidikan Antikorupsi Berbasis Agama. Jurnal UIN Raden Fatah, 2 (1), 127-130.

Purwanto, Yedi. Dan Fauzy, Ridwan. (2017). Analisis Terhdap Hukum Islam Dan Hukum Positif Dalam Pemberantasan Korupsi di Indonesia. Jurnal pendidikan agama islam-Ta'lim 5 (2), 113-114. http://jurnal.upi.edu

Rasyidi. (2015). "Pendidikan Antikorupsi Dalam Pendidikan Agama Islam". Jurnal Tamaddun Ummah, Vol. 01 No. 01 (Oktober 2015).

Rosidah, Darul, Chatarina dan Listianingsih, Mariani, Dessy. (2016). Pendidikan Antikorupsi Teori dan Praktek. Jakarta: Sinar Grafika.

Siroj, Malthuf, A. (2016). Korupsi dalam Perspektif Hukum Islam Dan Strategi Pemberantasannya. Jurnal al-Ihkam. 6 (2). http://www.jurnal.unsyiah.ac.id.

Sada, H. J. (2015). Pendidik Dalam Perspektif Al-Qur'an. Al-Tadzkiyyah: Jurnal Pendidikan Islam, 6 (1), 93-105.

Wahidin, A. (2018). Prinsip Saling Rela dalam Transaksi Ekonomi Islam (Tafsir Analisis Surat An-Nisa' 4 ayat 29). Jurnal Ekonomi dan bisnis Islam, 2 (2), 110-134 https://jurnal.staialhidayahbogor.ac

Zuhaili, W. (1997). Konsep Darurat Dalam Hukum Islam (Studi Banding Dengan Hukum Positif). Jakarta: Gaya Media Pratama. 
